\title{
Aid, trade and taboo: the place of indigenous traditional knowledge in development strategies: a Pacific perspective
}

\section{Sue Farran}

To cite this article: Sue Farran (2014) Aid, trade and taboo: the place of indigenous traditional knowledge in development strategies: a Pacific perspective, Development Studies Research. An Open Access Journal, 1:1, 28-41, DOI: 10.1080/21665095.2014.909289

To link to this article: https://doi.org/10.1080/21665095.2014.909289

$$
\begin{aligned}
& \text { (c) } 2014 \text { The Author(s). Published by } \\
& \text { Routledge. }
\end{aligned}
$$

\section{曲 Published online: 17 Jun 2014.}

Submit your article to this journal ๘

Џll Article views: 1627

View Crossmark data ¿ 


\title{
Aid, trade and taboo: the place of indigenous traditional knowledge in development strategies: a Pacific perspective
}

\author{
Sue Farran* \\ School of Law, Northumbria University, Newcastle upon Tyne, England
}

(Received 15 November 2013; accepted 25 March 2014)

\begin{abstract}
Pacific island countries (PICs) are examples of some of the least developed nations in the world. To improve their economic performance they are being urged to enter various trade agreements and in general to put in place frameworks to support twenty-first century priorities and international agendas including intellectual property regimes based, primarily, on western models. Yet PICs have long-standing traditional ways of safeguarding 'intellectual property'. Their traditional perceptions of this tangible and intangible cultural heritage are not always compatible with the models being proposed, both by their own governments and by external agencies with the consequence that initiatives to boost their small island economies may fail to take root among local communities or fail to recognize or protect the various forms of property and resources which are important to them and, in some cases, may have unforeseen adverse consequences. This paper uses examples from PICs to highlight the present failure of national and trans-national intellectual property regimes to adequately acknowledge the different approaches which indigenous people in the region have towards 'intellectual property' and consequences that this may have on their development in the current aid for trade environment.
\end{abstract}

Keywords: intellectual property; law; trade; development; Pacific islands

\section{Introduction}

In the context of trade and development, it is almost impossible to dissociate law and politics, especially when that development is also closely linked to foreign aid and intervention by third-party states and non-state entities. With this in mind, this paper looks at the relationship between aid-funded intervention and developments in intellectual property law, reflected through trade initiatives and imperatives in some of the least developed countries (LDCs) of the world. These are countries where aid is hugely important, where trade is extremely limited or imbalanced, and where intellectual property regimes are reflected in plural and often parallel legal systems, in which introduced laws and values derived from a colonial past operate alongside traditional, unwritten customary laws, practices and processes, enforced by prohibitions, public shaming, sorcery and in some cases banishment.

The link between intellectual property, traditional knowledge, indigenous culture, law and development is important because aid is increasingly dependent on, or directed at, trade expansion, integral to which is the capitalization of cultural tourism, the exploitation of genetic resources - for example, via bio-prospecting, and the commoditisation of expressions of culture: in short, the 'propertisation' of traditional knowledge, practices and cultural expressions. By this I mean the attribution of westerncentric legal perceptions of property to manifestations of traditional knowledge which traditionally have not been shaped or controlled by this type of legal discourse (see more broadly, Correa 2001). There are therefore dilemmas. If legal processes are to be used to provide appropriate protection to all forms of intellectual property (including traditional knowledge); create a facilitating environment for that property to be used to commercial advantage in the public domain, both for private and public benefit, and encourage a wide variety of players to engage with intellectual property (for example investors, manufacturers, pharmaceutical companies, recording studios, etc.), then ways have to be found to accommodate a diversity of agendas and priorities, not least of which is the trade-off between tightening laws on intellectual property favorable to developed countries but often seen as less attractive to developing countries (for example laws against piracy of material goods), and strengthening intellectual property laws which are more favorable and appropriate for developing countries but may be less attractive to developed

\footnotetext{
*Email: sue.farran@northumbria.ac.uk 
countries (for example stronger protections against biopiracy or environmental damage, greater recognition of the value of traditional knowledge and the complexity of values attached to cultural expression).

\section{PICs, SIDS and LDCs}

To illustrate the challenges, this paper focusses on one of the less-developed parts of the globe: the south-west Pacific, specifically Pacific island countries (PICs), which include over 20 states and territories, varying in size and with populations ranging from under 2000 in countries such as Niue and Tokelau to over six and a half million in Papua New Guinea (PNG). The total land area of the region including the Federated States of Micronesia and PNG is approximately 991,103 sq. km. but many of these countries consist of scattered small islands, some of them mere atolls, over a vast expanse of the Pacific Ocean. These factors present challenges for trade and development. While there are exploitable natural resources, notably mining in PNG, New Caledonia and to a lesser extent Fiji, Solomon Islands and Vanuatu; timber in PNG and Solomon Islands; and tuna fishing in the waters of Solomon Islands and Kiribati especially, these activities are not currently sustainable and the economic benefits do not remove aid dependency - even in resource-rich countries such as PNG. ${ }^{1}$ Most people in these islands rely on subsistence economies. There is virtually no industrialization and very limited manufacturing. Employment outside the exploitation of natural resources is in public service, commercial agriculture and tourism.

In a global context, the United Nations (UN) Committee for Development Policy has designated 48 countries to be LDCs. Measured by three indices: gross national income per capita, human assets and economic vulnerability, these countries are recognized as facing 'severe structural impediments to sustainable development' (UN website). Only some PICs are listed as LDCs with Samoa expected to graduate off the list in 2014 and Vanuatu before 2020. All PICs are however categorised by the UN as Small Island Developing States (SIDS) (Table 1). Commenting on SIDS, UNESCO observes

Facing a future whose only certainty is change, small island developing states are confronted with many problems and difficulties - some intrinsic and timeless, others extrinsic and new - in making progress towards sustainable living and sustainable development. ${ }^{2}$

PICs are countries with strong traditional social organization, a rich cultural heritage and evident attachment to custom, customary practices and customary laws, recognized both formally and informally within their legal systems and in many cases strengthened post-independence. While conservative advocates of traditional knowledge may claim that
Pacific people practice and observe traditional knowledge on a daily basis, it should be pointed out that an increasing percentage of the population are urbanized, educated and in waged employment. ${ }^{3}$ Even those who rely on subsistence agriculture also need money to meet daily needs, and traditional skills provide the means for earning cash as well as being important for daily life. There are consequently internal tensions regarding the pace and form of development as well as external pressures. As a spokesperson for the Pacific Institute of Public Policy has indicated, 'Pacific Islands living in debt often dance to the tune of those who provide much needed resources' (Islands Business 2014).

\section{The global and international background}

The localised and often small-scale concerns of PICs exist against a much broader backdrop of international conventions and statements. Often these have little immediate bearing on Pacific island people either because countries have not signed up to them (Table 2$)^{4}$ or because there is little or no connection between statements made by Pacific governments in the international domain and practical effect back home, or because there is very little general awareness of these international instruments. However, this background is relevant for major funding agencies who may be providing aid to PICs as part of a global package or program and because various treaty and convention bodies, and linked events, provide opportunities for PICs, usually in concert with others or regionally, ${ }^{5}$ to express their views and concerns. While not all aspects of this wider context can be included here, reference is made to UN Declaration on the Rights of Indigenous People (UNDRIP), ${ }^{6}$ the Agreement on Trade Related Aspects of Intellectual Property Rights (TRIPS), ${ }^{7}$ the Convention on Biological Diversity (CBD) and the International Treaty on Plant Genetic Resources for Food and Agriculture (TPGRFA).

\section{Pacific islanders as indigenous people}

Indigenous people represent the majority of the population in all PICS. This is relevant in so far as UNDRIP specifically recognizes the rights of indigenous people

to practize and revitalize their cultural traditions and customs. This includes the right to maintain, protect and develop the past, present and future manifestations of their cultures, such as archaeological and historical sites, artefacts, designs, ceremonies, technologies and visual and performing arts and literature. (Article 11)

and Article 31(1) states:

Indigenous peoples have the right to maintain, control, protect and develop their cultural heritage, traditional knowledge and traditional cultural expressions, as well as the manifestations of their sciences, technologies and cultures, including human and genetic resources, seeds, 
Table 1. An overview of PICs.

\begin{tabular}{|c|c|c|c|c|c|c|}
\hline Country & SIDs & LDC & $\begin{array}{l}\text { Population: mid-2013 } \\
\text { estimate }\end{array}$ & Land sq. km. & $\begin{array}{l}\text { Sea EEZ sq. } \\
\text { km. }\end{array}$ & $\begin{array}{l}\text { GDP US\$ } \\
\text { thousands }\end{array}$ \\
\hline Cook Islands & Yes & & 15,200 & 237 & 1.8 million & 272,769 \\
\hline $\begin{array}{l}\text { Federated States of } \\
\text { Micronesia }\end{array}$ & Yes & & 103,000 & 701 & 2.9 million & 310,213 \\
\hline Fiji & Yes & & 859,200 & 18,333 & 1.26 million & $3,099,191$ \\
\hline Kiribati & Yes & Yes & 108,800 & 811 & 3.6 million & 170,542 \\
\hline Marshall Islands & Yes & & 54,200 & 181 & 2.1 million & 173,700 \\
\hline Nauru & Yes & & 10,500 & 21 & 320,000 & 85,337 \\
\hline Niue & Yes & & 1500 & 259 & 389,000 & 22,857 \\
\hline Palau & Yes & & 17,800 & 444 & 600,900 & 212,903 \\
\hline PNG & Yes & & $7,398,500$ & 462,840 & 3.1 million & $127,000,000$ \\
\hline Samoa & Yes & Yes & 187,400 & 2,924 & 120,000 & 675,729 \\
\hline Solomon Islands & Yes & Yes & 610,000 & 28,000 & 1.6 million & 927,390 \\
\hline Tokelau & $\begin{array}{l}\text { Not } \\
\text { listed }\end{array}$ & & 1200 & 12 & $\mathrm{n} / \mathrm{a}$ & $\mathrm{n} / \mathrm{a}$ \\
\hline Tonga & Yes & & 103,300 & 749 & 700,000 & 470,669 \\
\hline Tuvalu & Yes & Yes & 10,900 & 26 & 757,000 & 38,178 \\
\hline Vanuatu & Yes & Yes & 264,700 & 12,281 & 680,000 & 760,097 \\
\hline
\end{tabular}

Sources: EEZ, Exclusive Economic Zone; GDP, Gross Domestic Product; LDC data, Development Policy and Analysis Division un.org; SIDS data sidsnet. org; Land mass, population and GDP, SPC Statistics for Development Pocket Summary and Population Poster (2013); EEZ Pacific Islands Forum Secretariat, Member Countries forumsec.org.

medicines, knowledge of the properties of fauna and flora, oral traditions, literatures, designs, sports and traditional games and visual and performing arts. They also have the right to maintain, control, protect and develop their intellectual property over such cultural heritage, traditional knowledge, and traditional cultural expressions.

These related provisions would appear to be directly relevant to Pacific islanders, and certainly draw attention to the importance of cultural property and traditional knowledge, however, few PICs were present at the vote on the declaration, ${ }^{8}$ and of those that were, Samoa abstained, while major trading partners and Pacific neighbors Australia and New Zealand voted against it. ${ }^{9}$ Although in the longer term the Permanent Forum on Indigenous Issues may provide a useful platform for raising development issues that affect PICs, ${ }^{10}$ other international instruments are more immediately relevant to intellectual property issues and development.

While UNDRIP suggests that indigenous people have specific rights which may be distinguishable from the rights of non-indigenous people, and some might argue that increasingly global law making is acknowledging the importance of traditional knowledge (Ni 2011-2012), there is inconsistency across these different global responses. In particular there appears to differences of approach in respect of the TRIPS, the CBD and the TPGRFA.

Table 2. PICs treaty membership.

\begin{tabular}{|c|c|c|c|c|c|c|}
\hline PIC & UNDRIP & TRIPS & WTO & CBD & TPGRFA & Other \\
\hline Cook Islands & & & & Yes & Yes & \\
\hline FSM & Voted yes & & & & & \\
\hline Fiji & Absent & Yes & & Yes & & Berne Convention $^{a}$ \\
\hline Kiribati & Absent & & & Yes & Yes & \\
\hline Marshall Islands & & & & Yes & Yes & \\
\hline Nauru & Absent & & & Yes & & \\
\hline Niue & & & & Yes & & \\
\hline Palau & Absent & & & & & \\
\hline PNG & Absent & Yes & & Yes & & Paris Convention ${ }^{\mathrm{b}}$ \\
\hline Samoa & Abstained & & & Yes & Yes & \\
\hline Solomon Islands & Absent & Yes & & Yes & & \\
\hline Tokelau & & & & & & \\
\hline Tonga & Absent & & & Yes & & Paris Convention; Berne Convention \\
\hline Tuvalu & Absent & & & Yes & & \\
\hline Vanuatu & Absent & & & Yes & & \\
\hline
\end{tabular}

${ }^{\mathrm{a}}$ Berne Convention for the Protection of Literary and Artistic Works.

${ }^{\mathrm{b}}$ Paris Convention for the Protection of Industrial Property. 


\section{TRIPS}

TRIPS compliance is integral to World Trade Organization (WTO) membership and the treaty sets out the minimum levels of intellectual property laws required for a country to join the WTO. ${ }^{11}$ Although intended to address some of the concerns which surrounded the Berne Convention and the Paris Convention from the perspective of developing countries (for background see Drahos 2002), the shortcomings of TRIPS have been highlighted by Dutfield who observed:

TRIPS does not appear to provide many opportunities of which traditional peoples and communities can avail themselves. On the contrary, framing the issue of TK protection in the discourse of western intellectual property rights does not go very far unless it is embedded in much broader-based negotiations between traditional peoples and communities, national governments, businesses, and scientists in which the most fundamental concerns of these peoples and communities, such as self-determination (for indigenous peoples), territorial rights, and human rights, are openly and comprehensively addressed. (2001, 259-260)

\section{CBD}

Diverging from the TRIPS objective of developing individual rights and exclusivity through intellectual property laws, the $\mathrm{CBD}^{12}$ is aimed at promoting biodiversity through conservation, sharing and sustainable use and imposes obligations on member states to 'respect, preserve and maintain the knowledge, innovations and practices of indigenous and local communities embodying traditional lifestyles' (Article 16). These two international instruments seem to be pulling in different directions (Jain 1998-1999, 785-786), and perhaps reflect a more global lack of consistency found in co-existing rhetoric about indigenous rights, concern about climate change, the importance of the world's biodiversity and the need for the developed world to assist the developing world to meet Millennium Development Goals. However the CBD is recognized as a weak or soft convention when confronted by the enforcement mechanisms of TRIPS and the WTO. ${ }^{13}$ Even the Special Rapporteur on the right to food has cast doubts on the CBD's effectiveness, stating 'benefit-sharing as conceived under the Convention has failed: in spite of the existence of a number of laws in developing countries which foresee forms of direct benefit-sharing between the "owners" and “buyers” of genetic resources' (De Schutter 2009).

The CBD is now strengthened by the 2010 Nagoya Protocol, ${ }^{14}$ which establishes a set of rules to promote the fair and equitable sharing of benefits derived from the exploitation and commercialization of biodiversity. In particular there is provision in the Protocol in respect of circumstances where either the right to access genetic resources vests in communities or where these communities hold traditional knowledge about these resources. Similarly there are provisions which seek to ensure the equitable sharing of any benefits derived from the utilization of such resources or knowledge and provisions which seek to ensure participation by such communities of knowledge holders in any uses made of resources or knowledge (Kamau, Fedder, and Winter 2010). While there is scope to leave it to communities themselves to establish appropriate mechanisms to meet these aims, essentially the Protocol is directed at states meeting these obligations through domestic frameworks, model contracts, awareness-raising, capacity-building and ensuring compliance by third parties. There is also the problem that the Protocol appears to desegregate access to genetic resources from traditional knowledge so that monitoring access to and utilization of genetic resources are treated separately from access to and utilization of traditional knowledge - which appear not to require monitoring. ${ }^{15}$ The Protocol may ensure the 'stronger involvement of local and indigenous communities holding genetic resources and traditional knowledge', ${ }^{16}$ but will not necessarily create a totally level playing field. Ratification looks some way off and subsequent meetings of Conference of Parties to the Convention on Biodiveristy (COP) may need to address rather more robustly what is meant by some of the wide discretional terms used in the Protocol. ${ }^{17}$ Nevertheless, the Protocol does provide a starting point for national governments and local communities to consider what steps they might take to ensure better control of their genetic resources and traditional knowledge. However, although a number of PICs have ratified the CBD none have incorporated this into domestic law, and as pointed out by FAO, 'the CBD does not explicitly state that national implementing laws must require access-seeking parties to obtain PIC (prior informed consent) from indigenous and local communities or traditional knowledge holders', so that one of the main aims of the $\mathrm{CBD}$, to prevent bio-piracy, may be thwarted (see more broadly, von Silke 2008).

\section{PGRFA}

The FAO's 2001 International Treaty on Plant Genetic Resources for Food and Agriculture (PGRFA) is also directed at benefit sharing, conservation and sustainability, ${ }^{18}$ and indeed action for PIC membership was recently urged at a special meeting of the Secretariat of the Pacific Community (SPC) in December 2013, ${ }^{19}$ at which it was stated: 'No country is self-sufficient in plant genetic resources. This is not a myth but a reality in the world today, and it is based on real evidence'. ${ }^{20}$ Article 9(1) recognizes the relevance of the contribution of traditional knowledge and practices of generations of indigenous communities and farmers, especially those in the developing world (Oguamanam 2006, 287-292), but it has been suggested that it needs to extend beyond benefit-sharing 
to include the protection of 'customary rights over genetic resources and associated landscapes, cultural and spiritual values and customary laws' (Argumedo et al. 2014). Where countries are signed up to the CBD this influences how PGFRA agencies can operate, ${ }^{21}$ as indicated in Table 2; however, only four PICs have signed up to PGFRA so far.

\section{WIPO}

The World Intellectual Property Organization (WIPO) is also working on a draft text for the protection of traditional knowledge, which could, if approved, become an international treaty. The Intergovernmental Committee on Intellectual Property and Genetic Resources, Traditional Knowledge and Folklore of WIPO held meetings in 2013 to consider genetic resources, traditional knowledge and traditional cultural expression with further meetings scheduled for 2014. The declared aim of such an international instrument would be to "define what is meant by traditional knowledge and traditional cultural expressions, who the rights holders would be, how competing claims by communities would be resolved, and what rights and exceptions ought to apply' (WIPO n.d.). While WIPO appears to recognize that 'there are divergent views on the best ways forward, including whether intellectual propertytype rights are appropriate for protecting traditional forms of innovation and creativity' and provides funding for indigenous people to attend the various talks, the Euro-centric location of such discussions makes it probable that few PICs will attend.

\section{Economic development and dilemmas for intellectual property rights}

This potentially contradictory international environment is brought into sharp focus when economic development issues are raised. For some time now Pacific island governments have been involved in discussions surrounding trade agreements: between themselves as collective members of the African, Caribbean and Pacific States and the European Union (EU-ACP Agreements); between themselves and their near neighbors - Australia and New Zealand, under PACER and PACER Plus, ${ }^{22}$ and globally under accession negotiations with the WTO. ${ }^{23}$ Trade agreements have the support of external agencies - especially aid donors who would like to see more effort being made by Pacific island states to nurture their own economic development (AusAID 2006; World Bank 2002). Most Pacific islands, however, have very little to export, ${ }^{24}$ so that although trade may be framed as a two-way process, most PICs are looking for inflows of investment, among which is the development of tourism ${ }^{25}$ and the receipt of aid. ${ }^{26}$

Aid, however, is increasingly being tied to trade as demonstrated by the WTO aid for trade initiative which was launched in 2005. A Background Note on the fourth Global Review, which was held in Geneva, 8-10 July 2013 explains:

\begin{abstract}
Aid for Trade is about helping developing and least-developed countries to improve their capacity to export goods and services, to integrate more effectively into the multilateral trading system and to benefit from increased market access opportunities. The initiative aims to assist developing countries in overcoming their supply-side constraints, build economic infrastructure and increase competitiveness. (WTO Aid for Trade 2013, 1)
\end{abstract}

The UNDP has indicated that LDCs, Landlocked Developing Countries and SIDS are particularly challenged by these 'supply-side constraints' which it explains as comprising, internally:

the lack of physical infrastructure, poor economic governance institutions, little access to rule of law, and a lack of healthy and skilled labor force. Externally, the complexity and structure of the international policy environment, which comprises a web of issues and rules related to global trade, investment, migration, intellectual property, debt sustainability and aid policy, prevents them from fully benefiting from globalization. (UNDP n.d.).

One of the projects under the aid for trade initiative is the WTO's Enhanced Integrated Framework (EIF) program. The aim of the EIF is to assist the world's poorest countries to 'integrate into the global trading system'. It draws on developed nations to provide aid to, among other things, 'build capacity to trade, which also includes addressing critical supply-side constraints' (WTO n.d.). In the context of addressing intellectual property issues, the combination of aid for trade and EIF presents an opportunity for developed countries to push for compliance with TRIPS by responding to the identified technical and other individual priorities and needs of LDCs. This in turn fosters WTO compliance either among those SIDs already members or those considering joining the WTO. This also aligns with the activities of WIPO. Intellectual Property for Development was at the core of Strategic Goal III of WIPO's 2010-2011 Strategic Framework and Program Structure, ${ }^{27}$ and remains a strategic goal in the framework for WIPO's six-year Medium Term Strategic Plan (2010-2015). The rhetoric behind IP for Development is that intellectual property (IP) is not an end in itself but rather is a tool that could drive countries' growth and development:

WIPO, as the lead United Nations agency mandated to promote the protection of intellectual property through cooperation among states and in collaboration with other international organizations, is committed to ensuring that all countries are able to benefit from the use of IP for economic, social and cultural development. (WIPO n.d.) 
The problem here is that these three aspects of development, 'economic, social and cultural', may not be compatible. Although WIPO acknowledges concerns about the unfair or inappropriate exploitation of traditional knowledge, traditional cultural expression and genetic resources, it also identifies these as offering considerable commercial promise and exploitation potential to contribute to economic development and its program utilizes key terms such as 'effective use', 'economic', 'commercial exploitation' 'life sciences', 'goals' and so on, suggesting therefore that the goals are being set primarily by western developed nations. Consequently where PICs seek to engage with law reform directed at IP for development, especially where any such law reform is aid-dependent, the agenda is likely to be one-sided and any accommodation of plural approaches, especially to traditional knowledge, will be challenging.

\section{Regional context}

While aid donors and other external agencies do engage with individual PICs, economies of scale favor regional initiatives. ${ }^{28}$ There are a number of regional organizations each with slightly different membership and different agendas. ${ }^{29}$ At the center is the Pacific Islands Forum Secretariat which is a regional political organization attended by heads of state and their ministers, depending on the occasion. ${ }^{30}$ It is the Forum which is most likely to discuss regional trade policy, although traditional knowledge-related issues can arise in connection with the work of any of these organizations. ${ }^{31}$ The policy objectives of the Forum are determined by the Pacific Plan, which is currently under review. At the 44th Pacific Islands Forum meeting held in Marshall Islands in September 2013, Pacific leaders noted, with reference to trade, the 'Regional Culture Strategy - Investing in Pacific Cultures 2010 2020' (Pacific Islands Forum Secretariat 2013, para 23). This strategy was mandated by the Pacific Plan of the Forum, ${ }^{32}$ designed by the Council of Pacific Arts and Culture and drawn up with the assistance of the SPC and adopted at the Pacific Arts Festival in 2012. ${ }^{33}$ One of the issues it responds to is to develop legislation to protect 'culture and heritage; promote cultural industries; and enlist greater government and donor partner support'. ${ }^{34}$ Protection and promotion may be difficult objectives to balance but represent twin concerns which have been ongoing for some time in the region.

In 1999, for example, Forum Trade Ministers highlighted the improper exploitation of the region's traditional and cultural resources without adequate compenzation being paid to custom owners, as well as incidents of such resources being exploited by third parties without informed prior consent. This in turn led to the drafting of a model intellectual property law for the Pacific in $20000^{35}$ The model law focuses on traditional knowledge and expressions of culture which are neither protected by customary law nor by introduced intellectual property law. In particular it encompasses intangible cultural property, works that originate and are managed by a collective or community, and works that are handed down from one generation to the next. It provides for traditional cultural rights to be held in perpetuity and to be inalienable. It proposes that any exploitation of cultural rights is governed by the law of contract with a number of safeguards in place to ensure that contracts are free and fair. This model law was endorsed for adoption by member countries of the Forum at a meeting of the SPC in 2003 (Secretariat of the Pacific Community 2002). It has not, however, been implemented so that the concerns expressed in the Pacific Community's Cultural Affairs Program, Strategic Plan for 2006-2009, remain valid:

Pacific Islanders' intellectual property, in particular their traditional knowledge and expressions of culture ... remain vulnerable to appropriation and commercialization for profit by outside interests. For example, handicrafts and souvenirs are being replicated outside the region and imported for sale as genuine items to tourists to the detriment of national handicraft industries. Music and images are recorded for publication without the permission of traditional owners. Medicines and plants have been patented with few benefits being returned to communities. No international or regional regime has legally protected these forms of culture. The international system of intellectual property recognizes individual ownership, is time-bound, and interprets the concept of 'invention' strictly so it does not adequately protect traditional knowledge, which has collective ownership, is held in perpetuity from generation to generation, is incremental and informal, and changes over time. ${ }^{36}$

While there is evidence of some ongoing discussion about appropriate regulatory models (South Pacific Forum 2002), it is also clear that there is impetus towards the commercialization of culture and the appropriation of traditional knowledge. For example, in a report commissioned by the SPC, and funded by the EU, it is stated

The cultural industries in the Pacific represent a wealth of
traditions, from ancient practices to contemporary cultural
expressions' and went on to explain that the purpose of
the report was 'to determine ways to harness the potential
of these industries to become drivers of economic growth
and to enhance sustainable development and well being
... to enable greater commercialization of Pacific cultural
goods and services. (McComb 2012)

In 2009 the EU committed funding of FJD 2 million for a project focussing on the development of 'cultural industries' in the Pacific region. Entitled 'Structuring the Cultural Sector in the Pacific for Improved Human Development' this initiative involves re-conceptualising culture as a means of generating economic growth. ${ }^{37}$ 
In March 2007 the Forum, which had assumed responsibility for the model law, convened a workshop with the aim of determining the needs of member countries' technical assistance to implement the model law at the national level. ${ }^{38}$ The conclusions and recommendations of that workshop were subsequently endorsed by Forum Trade Ministers, thereby retaining the close link between IP and trade. This has also been evident in the Pacific Traditional Knowledge Implementation Action Plan, which is based on a distillation of Forum Trade Ministers' directives since 1999 and has been drawn up against the wider international economic context impacting on Pacific island states and their economies and policies. ${ }^{39}$

The relationship between regionalism and national initiatives in the Pacific is an uneasy one. Broad policies and goals can be articulated at regional level, but international obligations and the implementation of laws takes place at a national level. Similarly international support for regional models is variable. ${ }^{40}$ For example, having been drafted at a regional level, the model law was then seen as only being suitable for national adoption rather than regional adoption. More recently a hybrid nationalregional approach has emerged with a shift to the longerterm objective of assisting the Forum PICs to establish a regional infrastructure based on mutual recognition of traditional knowledge and the establishment of an enforcement regime across boundaries, which would become operational on the basis of a multi-lateral treaty, ${ }^{41}$ in other words a cross-border enforcement mechanism regardless of internal differences of substance. In the hands of Trade Ministers however the focus seems to be on commercial intellectual property, notably trademarks, as evidenced in its 2011 report which noted that the Forum Trade Ministers had

considered an update on developments relating to Traditional Knowledge (TK) and Intellectual Property (IP) issues including the work being undertaken for the development of the Memorandum of Understanding for a Regional Trademark Applications System, the implementation of the Traditional Knowledge Action Plan and broader support provided to the Forum island countries on TK and IP work. (Pacific Islands Forum Secretariat 2011, 4)

\section{Indigenous people, traditional knowledge and cultural expression}

The above context of international and regional agencies, agendas and initiatives demonstrate that PICs are involved in a number of contemporary developments affecting intellectual property and traditional knowledge which give rise to various challenges.

At the outset the perception of traditional knowledge and traditional cultural expression (TCE), as property can be problematic. As stated by $\mathrm{Mr}$ Counsel, 'Indigenous culture is inseparable from heritage and defines the cultural identity of the Pacific islands and the community'. ${ }^{42}$ It is difficult, therefore, to isolate or separately archive traditional knowledge from traditional people. Both traditional knowledge and traditional cultural expression are aspects of the 'intangible cultural heritage' of indigenous people as well as the 'tangible heritage'.

Consequently indigenous cultural heritage, traditional knowledge, traditional expressions of culture (and here is not the place to go into the various difficulties and debates surrounding all these terms) do not always fit neatly into western-centric ideas about intellectual property, which are fundamentally based on a distinction between persons and things, nor do they match legal frameworks - such as copyright, trademarks and patents, which presume that individual authors, creators or inventors can be identified and rights extended to these from a particular moment in time and for a specific and limited period; similarly that it can be clearly ascertained who should receive the economic benefits of any intellectual property rights (Forsyth 2012), and that there is a framework and resources in place that can enforce these rights. ${ }^{43}$ Indeed, the development agenda is premised on clear formal legal frameworks in which IP laws are comprehensible to non-indigenous trading partners or investors. This is not to suggest that Pacific islanders do not control traditional knowledge and cultural expression:

Indigenous peoples possess their own locally-specific systems of jurisprudence with respect to the classification of different types of knowledge, proper procedures for acquiring and sharing knowledge, and the nature of the rights and responsibilities which attach to possessing knowledge. (Barsh 1999, 73)

The transmission of this heritage is through traditional means which may include secrecy, exchange, open practice, apprenticeship or imitation. Often the custodians of this knowledge and these traditions are collectives, sometimes they are individuals. The origins of a particular skill or manifestation of traditional knowledge may be attributed to a mystical or spiritual being, or be surrounded by secrecy and possibly magic. Intellectual property has traditionally been protected by the imposition of 'tabu' or custom prohibitions on the copying or performing of rituals, dances, music, songs, drawings or the practizing of traditional healing and so on. Breach of such traditional restrictions or prohibitions in the past might have attracted the sanction of the death penalty, stoning or banishment. Today it is likely to require custom compensation payments using a mixture of traditional wealth, such as foodstuffs, fine mats, pigs and cash or other western goods, and the efficacy of many traditional forms of enforcement are considerably less than they might have been in the past. In tra- 
ditional intellectual property regimes the use and dissemination of traditional knowledge is controlled by customary practices which are procedures as much as laws and any intellectual property rights, such as a right of performance, may be indistinguishable from the customary procedures which have to be observed to exercise those rights. But the legal systems of PICs are characterized by a plurality of laws in which customary law is only a part existing alongside laws emanating from national parliaments, and some left behind by colonial administrators or modeled on this legacy of colonial laws.

Originally the objectives of intellectual property laws introduced into the region were primarily to protect the intellectual property interests of non-indigenous persons. Subsequent national laws have, until recently, mirrored this western-centric approach. However, there is a growing awareness in the region that intellectual property laws modeled on western principles of ownership, alienability and commercial exploitation are not always appropriate for indigenous cultural property (Forsyth 2003a). This is not just a concern of Pacific islanders but of other indigenous people elsewhere. ${ }^{44}$ At the heart of the problem lies different perceptions of property and rights to that property. Pacific islanders traditionally make little distinction between tangible and intangible property, so that the idea of intellectual property being distinct from the plant, costume, mat or headdress that is the physical manifestation of myth, magic or identity is an anathema to many Pacific islanders (Kalinoe 2000). Nor have Pacific islanders traditionally needed a commercial incentive to create artistic works, perform dances or sing songs and there has been little incentive to create industrial designs, invent techniques of production requiring patents or manufacture products protected by distinct trademarks. Indeed the lack of cases brought before the courts suggests that many aspects of western forms of intellectual property are still of little or no significance in the region, at least not for indigenous people. Even if rapid development, the globalization of markets and increasingly frequent contact with outsiders prompted more national legislation, resourcing the administrative framework for the effective implementation and enforcement of western-style intellectual property laws presents considerable challenges for most PICs, and, given the rapid advances in the developed world in science and technology, it is likely that PICs will still be way behind the technology frontier however much aid is poured into them.

At the same time it should not be thought that traditional knowledge is static. It is not; rather it changes and adapts as the needs and experiences of people change. ${ }^{45}$ Moreover, not all Pacific islanders view indigenous culture in the same way. Some indigenous cultural custodians want to protect and preserve traditional knowledge and forms of cultural expression from commercial exploitation. Others see no problem with using what they have to generate income. They are happy to borrow from others and have others borrow from them; they engage in the global exchange of knowledge. Some want more state intervention others want less, the latter believing that the control of traditional knowledge should vest in individuals, in families and in communities. Similarly, opportunities for commercial benefits are likely to generate competing claims to rights of control and access to different elements of traditional knowledge, especially when it is increasingly viewed as a commodity and a means of generating cash in what are increasingly cashdependent economies, and also as the idea of intellectual property rights becomes more prevalent. Urbanization, the development of tourism, the influence of global media, the re-structuring of traditional society as a consequence of migration and emigration have also meant that many of the traditional customary forms of protection are becoming less effective. In a changing world there is also ambivalence towards intellectual property rights. Weak enforcement of existing laws means that 'pirated' goods, such as CDs, DVDs, clothing, accessories, books and so on, are cheaply and widely available. But weak enforcement also means that traditional cultural expression such as music, designs and songs can be easily 'stolen'; performances can be videoed and used for commercial purposes outside their countries of origin, handicrafts can be replicated with cheap, mass-produced copies, the biodiversity of the region can be exploited by pharmaceutical and agro-chemical companies and so on. Within PICs there is tension between those who embrace the commercial exploitation of indigenous cultural property or manifestations of traditional knowledge and those who are against this.

In trying to walk the tightrope between meeting the IP expectations of trade treaties, the concerns of traditionalists and the demands of Pacific artists and entrepreneurs, a number of PICs have sought to incorporate elements of traditional knowledge and expressions of culture within new national intellectual property laws.

As a result in the last decade there have been some initiatives to develop laws which address key issues raised by the Pacific context, notable traditional knowledge or indigenous intellectual property. Most of these have focussed on drafting copyright legislation which takes account of expressions of Pacific culture. For example in Tonga, the Copyright Act 2002, which came into effect in March 2004, includes 'folklore' within the scope of derivative works. 'Folklore' is defined as 'a group-oriented and tradition-based creation of groups or individuals reflecting the expectation of the community as an adequate expression of its cultural and social identity, its standards and values as transmitted orally, by imitation or by other means' ${ }^{46}$ However, little else in the 2002 Act makes concessions to the indigenous nature of folklore. There is, for example, a presumption that ownership or original authorship can be established and that where the intellectual property is collectively owned the copyright will be limited to a 
period of 50 years, ignoring thereby the inter-generational transfer of traditional knowledge.

In Samoa the Copyright Act $1998^{47}$ also deals with 'expressions of folklore', which it defines as 'group-orientated and tradition-based creation of groups or individuals reflecting the expectation of the community as an adequate expression of its cultural and social identity, its standards and values as transmitted orally, by imitation or by other means. $^{48}$.

Criticising similar provisions in PNG, Kalinoe (2000) has pointed out that while the definition of 'folklore':

is certainly comprehensive ... there is however no distinction made between secret/sacred material/expressions of folklore and those which are not. This is a cause for concern for general protection purpose and for allowing access, including the current forms of transaction and transmission of various and different classes of expressions of folklore either between generations or between neighboring communities. A distinction must be made between secret/sacred expressions of folklore and those which are not so in order that appropriate levels of protection can be instituted: perhaps absolute protection for those secret/ sacred material and a lesser level of protection for those which do not fall under that category.

The problem with the above is that accommodating traditional knowledge is still constrained by the concepts and forms of western copyright law. More innovative has been law brought into force in Vanuatu in $2011 .^{49}$ The Vanuatu Copyright Act, 2000 uses the term 'expressions of indigenous culture'. 'Indigenous culture' is interpreted to mean any way in which 'indigenous knowledge' may appear or be manifested. This includes all material objects; names, stories, histories and songs in oral narratives; dances, ceremonies and ritual performances or practices; and the delineated forms, parts and details of designs, visual compositions, specialised and technical knowledge and the skills required to implement that knowledge, including knowledge and skills about biological resources use and systems of classification.

'Indigenous knowledge' is stated as meaning any knowledge that is created, acquired or inspired for traditional economic, spiritual, ritual, narrative, decorative or recreational purposes; and whose nature or use of which has been transmitted from generation to generation; and that is regarded as pertaining to a particular indigenous person or people in Vanuatu. The rights afforded to indigenous culture are the same economic rights which are conferred on standard copyright rights and performance rights. ${ }^{50}$ Where these rights are infringed and the infringer is not a custom owner of the expression of indigenous culture, or the expression has not been sanctioned or authorised by the custom owners, or has not been done in accordance with the rules of custom, then the custom owners may institute an action against the infringer. ${ }^{51}$ Alternatively the chiefs of the locality of the traditional custom owners may ask the National Cultural
Council or the National Council of Chiefs (created under the Constitution of Vanuatu) to institute proceedings. The Vanuatu National Cultural Council is a statutory body and is custodian of expressions of indigenous culture. ${ }^{52}$ If it is not possible to identify who the custom owners of the expression are, then either of the above two bodies may institute proceedings. Any damages awarded in a successful action to either of these two bodies must be used for the purposes of indigenous cultural development. ${ }^{53}$ As is the case elsewhere in the region, there will not be an infringement of copyright where copies are made for exclusively personal purposes, for supporting the reporting of current events or where used for teaching. However, it is not necessary to establish that the infringer was making copies for profitmaking purposes and it does not matter when the expression of indigenous culture first came into existence. Where expressions of indigenous culture are published, the source and location of that source must be indicated. The Act also envisages the possibility of concurrent communal rights and individual rights over expressions of indigenous culture under different provisions of the Act. ${ }^{54}$

This piece of legislation is currently more extensive than that of other PICs in seeking to bring indigenous intellectual property rights within the scope of the law. It is however fraught with difficulties and inconsistencies, notably in its enforcement and administrative structures and in its retention of concepts of ownership and community rights. ${ }^{55}$

Despite these initiatives there is the continuing problem that legislation is trying to fit an acceptable internationally recognized formula which will accommodate the safeguards demanded by non-indigenous IP right holders for example to protect against piracy, while at the same time trying to protect indigenous right-holders and accommodate other indigenous users of traditional knowledge. Conferring property rights on an identified few may mean that many are excluded, while failing to do so may mean that traditional knowledge is seen as belonging to no-one and therefore open to exploitation. At the same time, new frameworks for intellectual property rights may mean that the role of traditional mechanisms for regulating traditional knowledge and cultural property are often marginalized or are seen as being extra-legal or in a parallel universe. For example, customary practices are traditionally mediated by elders and other men and women of higher customary status, for example, chiefs and councils of chiefs, who may have no formal place in the legislation. Similarly, the legal framework may fail to distinguish between traditional knowledge and traditional cultural expressions which are in the public domain because they are important for all members of the community to know and experience, and restricted access to other categories of traditional knowledge or expressions of culture which have to be purchased or earned, or which in custom are regarded as secret or private and only communicated to a selected few - to the extent that misuse or abuse may attract severe sanctions 
including punishments through sorcery. At the same time however, it has to be recognized that any customary regime for regulating traditional knowledge/traditional cultural expressions only works effectively in-country, where it is widely respected by the general population and policed and enforced by elders, chiefs and chiefs' councils. These measures are, however, often weak or ineffective against outside forces, non-indigenous third parties or where there is considerable mobility of Pacific islanders.

\section{Continuing challenges for advancing intellectual property regimes}

These are challenging times for intellectual property laws in the region. On the one hand, there is the pressure, both internal and external, to put laws in place to meet the criteria for WTO membership or in response to ACP-EU partnership negotiations or other trade agreements, in other words to take commercial advantage of indigenous intellectual property as a potential economic development sector. To date the framing of IP laws has been largely determined by actors and factors beyond the region, as evidenced by existing laws on patents, industrial designs and trademarks. While such laws may be beneficial to a small number of local industries and commercial enterprises, they are for the greater part directed at protecting global and foreign corporations and represent non-indigenous interests. At the same time however, it is questionable whether strengthening the intellectual property laws of an undeveloped or under-developed country without taking into account the values and context of the locality improves development. Often all that happens is that the developed countries which trade with less-developed ones benefit from the intellectual property laws there. One of the consequences of this is that many products become more expensive for Pacific islanders. On the other hand, there is increasing regional recognition of the risk that what is unique to Pacific islanders, for example their culture, designs, dance, ceremonies, plant knowledge or genetic resources, will be taken from them, developed by outsiders and exploited beyond their control and without greatly benefitting them. There is therefore a need to record, preserve and protect indigenous intellectual property in ways which are compatible with and take into account traditional safeguarding mechanisms for indigenous knowledge but are cognizable to outsiders. It is also clear that national laws in small island developing states, and the legal machinery required to enforce them, are insufficient by themselves to ensure protection. It is this realization that has prompted regional organizations to advocate a regional framework, ultimately framed in a treaty, for the protection of traditional knowledge and expressions of culture, alongside national measures. The problem with treaties, as seen with even the established international treaties mentioned above, is that they may be flawed or weak instruments.
The internal conflict about the best approach to intellectual property is not always simply about commercial exploitation or non-exploitation but about the processes observed in moving from the latter to the former, or the division of benefits once cultural property is in the public domain. Tourists, for example, are keen to see manifestations of traditional knowledge and indigenous cultural expression, and hotels and resorts prepared to pay performers, even if the performers do not own the rights to the spectacle and may not have obtained the necessary consent. Alternatively, traditional custodians may permit performances to strangers or in a different location subject to customary approvals and the observance of sanctions or restrictions - for example, spectators may be requested to keep a certain distance from the event or asked not to take photographs, in order to earn cash either for themselves and their families or the wider community. Unfortunately tourists do not always respect these limitations and there is little that performers or custodians can do about it. Indeed, it has been suggested by a former director of the cultural center in Vanuatu that 'What communities lack control over (and require assistance with) is instances of the commercial misuse of traditional knowledge/traditional cultural expressions and the use of traditional knowledge/traditional cultural expressions by outsiders' (Regenvanu 2006).

Even where national legislation is implemented which recognizes plural claims to intellectual property there are problems of management of the property itself and any economic benefits it engenders. Legal institutions such as trusts, co-operatives, incorporated associations or companies, all of which are introduced concepts, have met with mixed success in the region. Where a centralized agency is established or appointed to administer cultural property then its legal status may be uncertain, or its location and services inaccessible to people in remote or distant communities, or its governance suspect. Where national governments act on behalf of the people of the country there may be a lack of democratic participation and an inequitable distribution of benefits. ${ }^{56}$ In the Pacific where central government is often unstable and good governance is an issue, national laws or state commitments to international obligations may mean very little.

\section{Conclusion}

At a global level there has been recognition (some might say token) of the need for the developing and less affluent world to have a voice in the global drive towards more rather than less intellectual property rights (IPRs) (Yamin 2003), and PICs alongside other SIDS and LDCs may be able to harness the support of non-government organizations to lobby for more effective responses to their concerns. ${ }^{57}$ For example, PICs could, via the various UN forums such as the Permanent Forum on Indigenous People and its Inter-Agency Support Group and the UN 
Office of the High Representative for LDCs and SIDS, ${ }^{58}$ lobby for the recognition in the global arena that some intellectual property should belong to the global commons as a quid pro quo of the equitable distribution of responsibility for things like global warming and climate change, and that one way of achieving equitable restitution would be to use the technological superiority of developed countries to support those who are well behind the technological frontier within the framework of an agreed global commons of intellectual property.

At a regional level and in combination PICs may be able to negotiate more equitable trade agreements that incorporate terms which achieve more favorable IP rights for Pacific island people. The problem, in the context of PICs, however remains: intellectual property law seems to be inherently contradictory. On the one hand, it is there to protect the intellectual endeavor of the creator. Its presence is intended to encourage such endeavors so that the outcomes can bring benefits - usually commercial, to the public and to the creator. On the other hand, the conferment of exclusive property rights, the incentivization through potential commercial gain and even the publication itself may undermine the protection demanded by the rights of others. Western-centric perceptions of this area of law are firmly grounded in theories of property based on ownership, markets and money. They depend on clear definitions and points in time which the fluidity of customary organization may elude. While most non-indigenous models of intellectual property law fail to address the complex nature of traditional knowledge and its various manifestations it is also clear that recent in-country law reforms struggle to come up with regulatory regimes which can cover the diversity of interests in rapidly changing societies.

The dilemma for the twenty-first century intellectual property regimes in Pacific island states is therefore how to preserve the important social and cultural dimension of intellectual property in the indigenous context while shaping laws that meet national, regional and international trade and development demands.

\section{Notes}

1. In 2011, PNG received AUS $\$ 500$ million, representing $70 \%$ of all overseas development aid to PNG 'Australia's foreign aid spending: how much and where? Get the data' Global Development, The Guardian 22 August 2013, and Islands Business (2014) indicated that overseas development to the region amounts to ' 469 dollars per capita, compared to 64 dollars in Caribbean small states and 54 dollars in SubSaharan Africa'.

2. Small Island Developing States UNESCO.org.

3. The latest statistics from SPC, for example, indicate the percentage of total population as urban as follows: Cook Islands 74\%; Federated States of Micronesia 22\%; Fiji 51\%; Kiribati 54\%; Marshall Islands 74\%; Nauru 100\%; Palau 77\%; PNG 13\%; Samoa 20\%; Solomon Islands
20\%; Tonga 3\%; Tuvalu 47\% and Vanuatu 24\% (SPC Statistics for Development Pocket Summary and Population Poster November 2013).

4. The different degrees of membership will not be explored here. In some cases PICs succeeded to international obligations on independence, in some cases they have signed but not ratified or only ratified. Few have given any effect to international treaty obligations in national law.

5. For example, through the Alliance of Small Island States or the regional bodies of the Pacific Islands Forum Secretariat (formerly the South Pacific Forum until 1999 when the name changed), the Secretariat of the Pacific Community (SPC) or the Pacific Islands Development Forum (PIDF n.d.) (each of which incidentally has a slightly different PICs membership).

6. This is not a treaty but a declaration which was adopted by the General Assembly in September 2007 supported by 144 UN members.

7. 1 January 1995.

8. Consequently PICs had very little input into the framing or approval of this international instrument.

9. UN Resolution A/RES/61/295 Voting Summary, United Nations Bibliographic Information System unbisnet.un. org. Similarly only Fiji has ratified the ILO Indigenous and Tribal Peoples Convention No. 169, 1989.

10. There is, for example, to be a World Conference on Indigenous Peoples in 2014, Resolution A/Res/66/142, 19 December 2011. However, the Pacific Declaration of the Preparatory Meeting for Pacific Indigenous Peoples on the World Conference on Indigenous Peoples 2014, of 19-21 March 2013 makes reference to the corporatization and commodification of Indigenous peoples and their worlds'. http://www.un.org/esa/socdev/unpfii/documents/WCIPPacific-Statement-Outcome-Document.pdf (Accessed 3 February 2014).

11. The aim behind TRIPS compliance was to arrive at global standardization but this has not been achieved (Binkert 2004-2006). In particular, she points out that traditional knowledge is not sufficiently protected under the TRIPS framework.

12. This was agreed at the Rio Earth Summit in 1992.

13. On the potential conflict between the aims of the CBD compared to TRIPS (GRAIN 1998; Jain 1998-1999).

14. The Nagoya Protocol on Access to Genetic Resources and the Fair and Equitable Sharing of Benefits Arising from their Utilization to the Convention on Biological Diversity was adopted at the 10th Conference of Parties to the Convention on Biodiversity (COP10) at Nagoya, Japan, in October 2010. The Protocol is seen as particularly important for the third aim of the CBD the equitable sharing of benefits, which is regarded as underpinning the other two aims: conservation of biodiversity and sustainable use of biological resources.

15. Ibid., 253.

16. Ibid., 262.

17. Ibid. Kamau highlights terms such as: 'as appropriate', 'where applicable', 'as far as possible' and 'if available' and points to the weak language that pervades the Protocol.

18. Initially a non-binding International Undertaking on Plant and Genetic Resources (PGR) agreed in 1983, which advocated the sharing of plant genetic material as the "heritage of mankind' and sought to ensure that farmers and informal generators of PGR were appropriately rewarded. Cooks Islands, Kiribati, Fiji, Samoa, Palau and Australia are regional signatories. 
19. SPC Urges Islands to Sign International Plant Resource Treaty, 11 December 2013. http://archives.pireport.org/ archive/2013/december/12-12-rl2.htm (Accessed 23 January 2014).

20. By Mr Samu Turagacati, "SPC Increasing Agricultural Commodity Trade project". Team Leader on behalf of the Director for Land Resources Division.

21. See FAO above.

22. PACER is the Pacific Agreement on Closer Economic Relations. Details can be found at http://www.forumsec. org/resources/uploads/attachments/documents/PACER.pdf. It is aimed at 'trade liberalization and economic integration in the Pacific region'. PACER Plus was launched by Forum Trade Ministers in 2009. Australia is a PACER partner and provides funding for the project. Australia and New Zealand are involved in PACER Plus.

23. Former colonies became members of the General Agreement on Tariffs and Trade (GATT) (the predecessor to WTO) on independence provided their colonial masters were GATT members. This was an interim provision and full membership, which would automatically lead in turn to WTO membership, through formal accession had to be applied for. WTO agreements are wider in scope than the former GATT membership and include legislative and regulatory reforms and market access concessions relating to goods and services, intellectual property rights and investment ventures. Countries of the region which are members of the WTO are Fiji (14 January 1996), Papua New Guinea (9 June 1996) and Solomon Islands (26 July 1996) and Tonga (2007). Vanuatu and Samoa joined the WTO in 2012.

24. Hezel (2012) states that for most PICs, excepting Fiji, PNG and Solomon Islands, exports amount to $10 \%$ or less of GDP.

25. Other inflows include remittances from the Pacific diaspora, licences for foreign fishing vessels, logging licences for foreign timber companies and the provisions of certain financial services (tax havens).

26. Hezel $(2012,23)$ suggests that often aid is not contributing towards development but is being used to meet shortfalls in national economies especially in public sector spending. See also Feeney (2005) and Hughes (2003).

27. Facilitating the use of IP for development, under the WIPO Strategic Framework and Program Structure of Program and Budget 2010-2011.

28. One of the issues that PICs face is that they are often considered under the very broad umbrella 'Asia-Pacific' or in the case of the EU, with Africa and the Caribbean under the ACP label.

29. The SPC describes itself as 'an international organization that works in public health, geoscience, agriculture, forestry, water resources, disaster management, fisheries, education, statistics, transport, energy, human rights, gender, youth and culture to help Pacific Island people achieve sustainable development' Secretariat of the Pacific Community (2014b). The PIDF focuses on developing strategies for sustainable development 'through a green economy in Pacific Island Countries'.

30. For example Ministers of Tourism may meet to discuss regional tourism policy while Trade Ministers will meet to discuss regional trade policies and treaties. The absence of multi-ministerial meetings is an obstacle to developing coherent strategy on IP.

31. TK relating to fisheries management and agricultural practices is important for the work of the SPC, while TK for conservation and the sustainability of the environment are relevant to the work of PIDF.

32. Objective 11.1 of the previous Pacific Plan was to recognise and protect 'cultural values, identities and traditional knowledge'.

33. This regional cultural event is held every two years and in 2012 was hosted by Solomon Islands.

34. Makereta Komai 2012 'Pacific Ministers Back Regional Cultural Strategy' SPC/PACNEWS, 6/07/2012, Solomon Islands http://pina.com.fj/index.php?p=pacnews\&m=read\& o=319970644ff69110ea97ef6ab55b92 (Accessed 19 April 2014).

35. The Model Law for the Protection of Traditional Knowledge and Expressions of Culture (for background see Kalinoe 2000; Forsyth 2003b).

36. http://www.spc.int/culture (Accessed 6 July 2012).

37. The stated aims are (1) The development of cultural policy in six countries; (2) The promotion of cultural industries to the European Union and intra-ACP through the development of a marketing strategy bringing public, private sector and civil society organizations together; (3) The mapping of threatened cultural heritage sites and (4) Exchanges between Pacific and Caribbean museums (Secretariat of the Pacific Community 2014a).

38. Any such technical assistance is, of course, likely to require aid-funding.

39. Implementation of the plan is itself aid dependent. In 2009 funding of USD $\$ 570,400$ for a two-year project was allocated to Cook Islands, Fiji, Kiribati, Palau, PNG and Vanuatu. Apart from facilitating Vanuatu's WTO accession and PNG preparing to host the Examining Body for the Regional Trademarks Application System, it is not clear what has been achieved.

40. For example, the WIPO Intergovernmental Committee on Intellectual Property and Genetic Resources, Traditional Knowledge and Folklore, held in Geneva during 13-21 June 2002, did not support the examination of possible measures for the regional and international protection of expression of folklore.

41. However this is largely dependent on uniform national regimes and would also be dependent on a co-ordinated legal approach to the protection of the region's TK, including the mutual recognition and enforcement of rights and obligations between participating jurisdictions. To date PICs have not demonstrated this degree of mutuality.

42. The Fijian Permanent Secretary of iTaukei Affairs at the 5th Pacific World Heritage Workshop held in Suva in November 2013 UNRSCO 30 December 2013. http://www.unesco.org/ new/en/apia/about-this-office/single-view/news/ indigenous_culture inseparable from heritage and identity_of_the_pacific_community/\#.Uu_aMdGYaog

43. See practical problems in Fiji, Daurewa (2013).

44. See for example the UNESCO (1999) and the Australian cases of Yumbulul $v$ Reserve Bank of Australia [1991] 2 IPR 481 and Milpurrurru and others $v$ Indofurn Pty Ltd [1995] 30 IPR 209.

45. For example, new materials may be used for traditional costumes, or modern tools used for making traditional canoes or carvings.

46. Sections 2 and 4.

47. Part IV (Section 2).

48. The definition of expressions of folklore is similarly defined in PNG under Part V of the Copyright and Neighbouring Rights Act 2000, and the scope of the protection is similar to that of Samoa. In Fiji, expressions of folklore are included 
within the meaning of 'public performance', and special reference is made to the recording of folk songs.

49. The law was drafted in 2000. The delay in implementing the legislation is closely tied to the debates surrounding WTO accession and may also have been prompted by indigenous musicians finding a champion in Parliament to advocate protection for their compositions and recordings.

50. Indigenous rights are recognised under Section 8(1) and standard rights under Section 23(1).

51. Section 42 read with 34 and 23.

52. Established under the Vanuatu National Cultural Council Act (Cap 186).

53. Section 42(4).

54. For example where one group claims performance rights and an individual claims film rights.

55. For example the notion of community and communal or collective rights is widely used without specificity, and it is unclear whether all claims are to be heard by informal customary forums or will be appealed to formal courts, and if so how these will be constituted.

56. For example, in 2004, the government of Samoa entered into a bilateral agreement with the University of California: Memorandum of Understanding with the University of California at Berkley regarding the division of economic return from research into Prostratin Gene Sequences, an Anti-Viral Molecule [2004] PITSE 1 (13 August 2004). Similar attempts by the Tongan government to commercially exploit a gene pool met with considerable opposition once the media got hold of the story and the project had to be abandoned.

57. See Dutfield above on the effective impact of NGOs on the CBD.

58. Although geographically small, and economically weak, numerically Pacific island states represent $29 \%$ of the total number of SIDS, $6 \%$ of UN membership and have their own informal lobby group: the Pacific Small Islands Developing States.

\section{References}

Argumedo, A., K. Swiderska, M. Pimbert, Y. Song, and R. Pant. 2014. "Implementing Farmers Rights under the FAO International Treaty on PGRFA: The Need for a Broad Approach Based on Biocultural Heritage." Paper prepared for the Fourth Governing Body of the International Treaty on PGRFA, Bali 14-18 March 2011. Accessed February 7, 2014. http://pubs.iied.org/pdfs/G03077.pdf

AusAID. 2006. "Pacific 2020: Background Paper the Regional Economic Agenda." Accessed February 3, 2014. http://aid. dfat.gov.au/Publications/Documents/background_economic. pdf

Barsh, R. 1999. "Indigenous Knowledge and Biodiversity, in Indigenous Peoples Their Environments and Territories." In Cultural and Spiritual Values of Biodiversity, edited by D. Posey, 73. London: Intermediate Technology Publications/ UN Environment Programme.

Binkert, B. 2004-2006. "Why the Current Global Intellectual Property Framework under TRIPS is not Working." Intellectual Property Law Bulletin 10 (2): 143-162.

Correa, C. 2001. "Traditional Knowledge and Intellectual Property: Issues and Options Surrounding the Protection of Traditional Knowledge.” A discussion paper, QUNO. http:// www.quno.org

Daurewa, J. 2013. "Copyright Prosecution - The Fiji Experience." Pacific Studies 36 (1/2): 105-112.
De Schutter, O. 2009. "Right to Food.” UN Report A/64/170.

Drahos, P. 2002. "Developing Countries and International Intellectual Property Standard-Setting." Journal of World Intellectual Property 5 (5): 765-820.

Dutfield, G. 2001. "TRIPS-Related Aspects of Traditional Knowledge." Case Western Reserve Journal of International Law 233-276.

FAO. 2004. "Obligations for National PGRFA Programme Managers." Accessed February 7, 2014. http://www.fao.org/ docrep/007/y5636e/y5636e 02.htm

Feeney, S. 2005. "The Impact of Foreign Aid in Papua New Guinea." The Journal of Development Studies 41 (6): 1092-1117.

Forsyth, M. 2003a. "Intellectual Property laws in the South Pacific: Friend or Foe?" Journal of South Pacific Law 7 (1). http://www.paclii.org/journals/fJSPL/vol07no1/

Forsyth, M. 2003b. "Cargo Cults and Intellectual Property in the South Pacific." Australian Intellectual Property Journal 14 (4): 193-207.

Forsyth, M. 2012. "Lifting the Lid on the Community: Who has the Right to Control Access to Traditional Knowledge and Expressions of Culture?" International Journal of Cultural Property 19 (1): 1-31.

GRAIN 1998. "TRIPS versus CBD.” Issue 1. Accessed June 22, 2013. http://www.grain.org/article/entries/20-trips-versus-cbd

Hezel, F. X. 2012. "Pacific Island Nations: How Viable are their Economies?" Pacific Islands Policy 7: 1-33.

Hughes, H. 2003. "Aid has Failed the Pacific.” Issue Analysis No. 33. Sydney: Centre for Independent Studies.

Islands Business.2014. "Pacific Nations Need Help Away from Aid." January 30. island business.com.

Jain, M. 1998-1999. "Global Trade and the New Millennium: Defining the Scope of Intellectual Property Protection of Plant Genetic Resources and Traditional Knowledge in India." Hastings International and Comparative Law Review 22 (4): 777-820.

Kalinoe, L. 2000. "Promulgating Traditional Knowledge Sensitive IPR legislation in Papua New Guinea and Related Developments in Pacific Island Countries: A Reflection on the Past Three Years." Melanesian Law Journal 27: 6. PacLII.org http://www.paclii.org/cgi-bin/sinodisp/journals/ $\mathrm{MLJ} / 2000 / 6 . \mathrm{html}$ ?stem $=$ \&synonyms $=\&$ query $=$ kalinoe

Kamau, E. C., B. Fedder, and G. Winter. 2010. "The Nagoya Protocol on Access to Genetic Resources and Benefit Sharing: What is New and What are the Implications for Provider and User Countries and the Scientific Community?" Law, Environment and Development Journal 6 (3): 246-262.

McComb, J. F. 2012. Development and Marketing Strategies for Pacific Cultural Industries, p. 1. Suva: SPC.

Ni, K.-J. 2011-2012. "Traditional Knowledge and Global Lawmaking." Northwestern Journal of International Human Rights10 (2): 85-118.

Oguamanam, C. 2006. "Intellectual Property Rights in Plant Genetic Resources: Farmers Rights and Food Security of Indigenous and Local Communities." Drake Journal of Agricultural Law 11 (3): 277-292.

Pacific Islands Development Forum. n.d. What is Pacific Islands Development Forum (PIDF)? http://pacificidf.org/what-is-pidf

Pacific Islands Forum Secretariat. 2011 "Foreign Trade Ministers Report." PIFS (11) FTM.

Pacific Islands Forum Secretariat. 2013 "Forum Communiqué." PIFS(13) 8.

Regenvanu, R. 2006. "Indigenous and Local Communities Concerns and Experiences in Protecting their Traditional Knowledge and Cultural Expressions." 9th Session of the Intergovernmental Committee on Intellectual Property and 
Genetic Resources, Traditional Knowledge and Folklore (IGC) of the World Intellectual Property Organisation (WIPO), Geneva, Switzerland, 24 April 2006.

Secretariat of the Pacific Community. 2002. "Guidelines for Developing National Legislation for the Protection of Traditional Knowledge and Expressions of Culture Based on the Pacific Model 2 and Regional Framework for the Protection of Traditional Knowledge and Expressions of Culture." Secretariat of the Pacific Community's Cultural Affairs Programme, Strategic Plan for 2006-2009.

Secretariat of the Pacific Community. 2014a. "Structuring the Cultural Sector in the Pacific for Improved Human Development." Accessed February 7, 2014. http://www.spc. int/en/our-work/education-training-and-human-development/ human-development/news/447-eu-grants-fjd-2 m-to-spc-forculture-programmes.html

Secretariat of the Pacific Community. 2014b. Dr Colin Tukuitonga "About Us." Accessed February 8, 2014. http://www.spc.int/en/ about-spc.html

Secretariat of the Pacific Community. 2013. Statistics for Development Pocket Summary and Population Poster. Accessed February 7, 2014. www.spc.int/sdd/

von Silke, S. 2008. Indigenous Heritage and Intellectual Property: Genetic Resources Traditional Knowledge and Folklore. AH Alphen aan den Rijn, The Netherlands: Kluwer Law International.

South Pacific Forum. 2002. "Regional Framework for the Protection of Traditional Knowledge and Expressions of Culture." http://www.forumsec.org.fj/resources/uploads/ attachments/documents/PacificModelLaw,ProtectionofTKand ExprssnsofCulture20021.pdf
UNDP. n.d. Trade, Intellectual Property and Migration. Accessed February 3, 2014. http://www.undp.org/content/undp/en/ home/ourwork/povertyreduction/focus_areas/focus_trade and investment/

UNESCO. 1999. "Report on the Symposium on the Protection of Traditional Knowledge and Expressions of Indigenous Cultures in the Pacific Islands." Noumea, February 15-19. Available at portal.unesco.org/culture/ed/files/14264/...pdf/ Noumea1999.pdf

WIPO. n.d. Intellectual Property for Development. Accessed November 15, 2013. http://www.wipo.int/ip-development/en/

WIPO. n.d. "Traditional Knowledge and Intellectual PropertyBackground Brief”. Accessed April 19, 2014. http://www. wipo.int/pressroom/en/briefs/tk_ip.html

World Bank. 2002. "Pacific Islands Regional Economic Report Embarking on a Global Voyage: Trade Liberalization and Complementary Reforms in the Pacific No. 24417-EAP." Accessed February 3, 2014. http://www-wds.worldbank.org/ external/default/WDSContentServer/WDSP/IB/2002/09/27/ 000094946_02091804042860/Rendered/PDF/multi0page.pdf

WTO Aid for Trade. 2013 "A Background Note on the fourth Global Review." Geneva, 8-10 July. Accessed February 3, 2014. http://www.wto.org/english/tratop_e/devel_e/a4t_e/ global_review13prog_e/global_review13 bord_e.pdf

WTO n.d. Enhanced Integrated Framework. Accessed February 3, 2014. http://www.wto.org/english/tratop_e/devel_e/teccop_e/ if_e.htm

Yamin, F. 2003. "Intellectual Property Rights Biotechnology and Food Security." Institute of Development Studies, Working Paper 203. Accessed January 23, 2014. http://www.eldis. org/vfile/upload/1/document/0708/DOC14100.pdf 